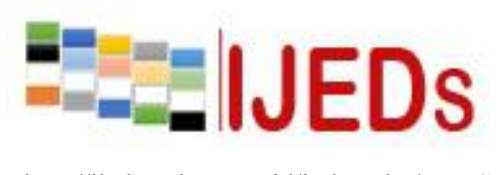

International Journal of Educational Dynamics

Vol. 1 No. 1 (pp. 136-146) December 2018

p_ISSN 2655-4852

e_ISSN 2655-5093

http://ijeds.ppj.unp.ac.id/index.php/IJEDS

\title{
GROWING SCIENTIFIC ATTITUDES AND WORSHIP TO SCIENCE FOR STUDENTS
}

\author{
*Hirma Meuthia ${ }^{1}$, Jon Efendi ${ }^{2}$ and Riska Ahmad ${ }^{3}$ \\ ${ }^{1,3}$ Graduate Program of Primary Education \\ Faculty of Education Science, Universitas Negeri Padang, Indonesia \\ ${ }^{2}$ Graduate Program of Chemical Education \\ Faculty of Mathematics and Science, Universitas Negeri Padang, Indonesia \\ E-mail: mutia.sonajah@gmail.com
}

\begin{abstract}
*Corresponding Author, Received: November 12, 2018, Revised: December 10, 2018, Accepted: December 21, 2018
\end{abstract}

\begin{abstract}
This study presents a literature review on growing scientific attitudes and literacy towards science for students. Natural science is a product, process, and ends with an attitude that is a scientific attitude. Scientific attitudes are developed through scientific literacy activities or processes in learning when conducting discussions, experiments, simulations, and project activities at the field. Although in the world of education, we have encountered many models that carry out the activities described above in developing students' scientific attitudes. Some of them are inquiry, discovery learning, problem-based learning, project-based learning, and contextual learning. The learning model improves the scientific attitude in learning. However, there are some obstacles in its efforts to foster the scientific attitude of students, one of the problems is that educators lack the relevant pedagogical skills needed in learning in an atmosphere of inquiry. Another disadvantage is that the background of teachers' understanding of scientific literacy content is still poor. This research was conducted to see the factors that influence the scientific attitude of students. Literature research results show that the scientific attitude of students will be positive, if the ability of educators in scientific learning and literacy of science is mastered by the teacher.
\end{abstract}

Keywords : Scientific Attitude, Literacy Attitude, Science

\section{INTRODUCTION}

Attitudes towards science include attitudes towards scientists, scientific attitudes and attitudes towards scientific careers, methods of education, interests related to scientific knowledge and the content of science (Aktamis and Ergin, 2008). The 


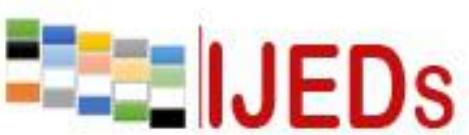

http://ijeds.ppj.unp.ac.id/index.php/IJEDS

structure with the learning environment can be crucial in overcoming the problem of the scientific attitudes of students who are not embedded in it. Eshach and Fried (2005) argue that teaching science to early primary school children promotes an inherent curiosity and encourages the growth of a positive attitude towards science. It should be noted that the views of students on science, the nature of science and scientists have a positive or negative influence over the selection of future professions and the level of performance of students in that area. Moreover, the relationship between perceptions of scientists and scientific attitudes is assessed by examining the scientific attitudes of students (Demirbas, 2009). It is about cultivating the academic attitude of students. There are several dimensions that must be owned by a science teacher, namely the academic / epistemic, professional and social dimensions. Academic / epistemic dimensions are based upon their understanding of scientific methods, observation, experiments and the use of models in science. Professional dimensions are based upon their experiences as teachers, and the social dimension is based on their personal and social experience with science. According to research, these dimensions reveal images of teacher chemistry (Désautels and Larochelle, 1989; Lederman, 1999) and how teachers relate to science (Charlot et al., 1992). This means knowledge and understanding of scientific concepts and processes that are necessary for personal decision making, participation in civil and cultural affairs and economic productivity (Turiman et al, 2012). Students with more advanced scientific literacy demonstrate the ability to use conceptual models to explain natural phenomena, to provide explanations, to evaluate alternative explanations of the same phenomenon, and to communicate explanations in the right way (Bybee, 2009).

Goncalves and Azevedo (2011) say that teachers offer different perspectives for teaching science in primary education. According to Harlen (in Nigro and Azevedo, 2011), this goal will be: 1 . It teaches children about science, 2. It teaches the skills, skills and attitudes of children who apply to every example of their lives, 3. To give scientific knowledge to children who are acceptable (the truth); 4. Start teaching the knowledge that will be learned in secondary education in the first cycle.

Moreover, more and more specialized literature has shown that science education must be aimed at forming individuals who understand the knowledge they 


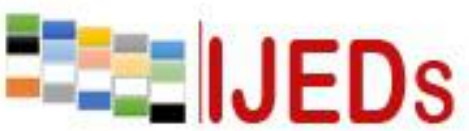

http://ijeds.ppj.unp.ac.id/index.php/IJEDS

encounter in their daily lives, who participate in decision-making processes based on scientific information, valuation science as part of culture, and are vigilant on moral and ethical issues that arise in the development of science (EILAM in Nigro and Maria Azevedo, 2011).

Ritter and Boas (2015) said in this process that the methodology used by the teacher would have a decisive difference. Problem-based learning (PBL) enables students to interact and conduct research, and teachers no longer have a primary role in the classroom. The focus is shifting to students who play an active role during the learning and learning process.

Viecheneski and Carletto (2013) suggests education science can help to put the students in a new culture, scientific culture, which allows them to see and understand the world with the critical factor of the larger and with the knowledge to differentiate, evaluate and make conscious choices in life every day they are, with a view to a better quality of life.

Arikan et al (2016) suggested using the term PISA mathematical literacy, scientific literacy and reading ability to encompass the broader concept of knowledge and skills in mathematics, science and reading. PISA literacy concept is based on the ability of students to acquire knowledge and skills to apply the various problems of mathematics, science, and reading as well as the challenges they face in their future lives. PISA offers an interest in the cognitive and affective aspects of students that can be applied to build competence in science. Cognitive aspects include knowledge and capacity of students, they are used effectively and relates to cognitive processes as one of the characteristics of science in the aspect of personal, social and global. Affective aspects associated with problems that can be solved with the scientific knowledge and form students who can make a decision in the current situation and the future (Afriana et al, 2016).

Sasseron and Carvalho (2013) identify three points that are most important when thinking about scientific literacy. Firstly, from the structural axis, referring to the basic notion of terms, the basic knowledge and scientific concepts and their importance are the needs that are needed in our society to understand key concepts and understand small information and situations today. Secondly, it relates to the nature of science and 


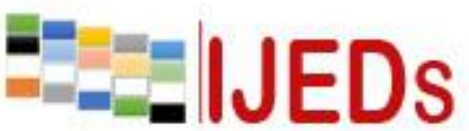

http://ijeds.ppj.unp.ac.id/index.php/IJEDS
International Journal of Educational Dynamics

Vol. 1 No. 1 (pp. 136-146) December 2018

p_ISSN 2655-4852

e ISSN 2655-5093

ethical and political issues surrounding practical factors, because in everyday life, when we are confronted with information and regulation, we must remember the context. Before we go any further. So, the scientific research is conducted, we can find grants for researching everyday problems with scientific concepts or knowledge that comes from them. Third, the AC is based on the recognition of the relationship between science, technology, society and the environment that is influenced in different ways, namely science and technology. In that sense, it is very important to do when we think about the desire for a healthy and sustainable future for society and the planet.

Part of the problems presented in science Plonczak (2008) deals with the background of teachers who are still poor in science content, making the teacher feel the science of educational science is not easy, and often lead to exclusion from science of their education priorities. Due to their lack of confidence in the content of sciences, primary school teachers often carry out activities in the classroom using the worksheet by copying and repeating textbooks. These learning practices that influence the understanding of scientific concepts and scientific attitudes of students do not develop. While students want to see the science side of the framework of activities of daily / contextual. For example: why an apple becomes darker when cutting in half is part of the experience of our daily life.

The same in the problems that Avraamidou (2014) raises is that teachers in primary education lack the relevant skills and / or pedagogical beliefs that are necessary to teach science. Teachers give less involvement of students in scientific practice, such as designing and conducting research (Christopher; Deborah, 2010). The main goal of science education is to 'cultivate students' scientific habits, develop their ability to participate in scientific research and learn to reason in a scientific context. In adding insight into this paper on science education, a description of the K-12 Science Education published in North America, as a basis for the development of new standards in K-12 scientific education (NRC, 2012). The overall goal for K-12 science education in North America is to ensure that: At the end of the lesson all students have an appreciation for the beauty and wonders of science; have sufficient knowledge about science and technology to participate in public discussions on related issues, and can continue to learn about science outside school. 


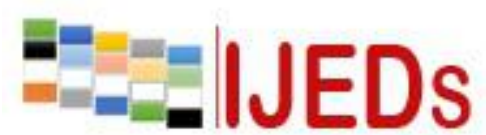

http://ijeds.ppj.unp.ac.id/index.php/IJEDS

\section{International Journal of Educational Dynamics}

Vol. 1 No. 1 (pp. 136-146) December 2018

p_ISSN 2655-4852

e ISSN 2655-5093

Gillies, Nichols, Burgh, Haynes (2013) suggested problems in the exact subjects are motivated by teachers in general do not ask questions in mind, and do not use spontaneously and activate their prior knowledge, unless expressly guided to do so and modeling the role of the teacher as a troubleshooter and the role of students as passive as recipients of teacher training.

Barnard (1953) states that the experience in science, the scientific attitude and skills of the students to promote, namely: 1) to know the phenomenon has questions about the student; 2) students are trained to think broadly / openly and respect the perspectives of other people; 3) recognize and clearly identify problems that need to be solved; 4) determine the elements of the problem that must be taken into account when solving the problem; 5) make effective use of the skills involved in finding, collecting, managing, understanding and testing the reliability of the information needed to solve problems; 6) design and evaluation methods (experiments, surveys, etc.) To obtain proof of problem solving;

Robyn, Nichols, Burgh, Haynes (2014) said that academic learning can promote the scientific attitudes of students, namely: 1) to ask questions to promote the curiosity of students; 2) generate hypotheses from student questions; 3) looking for evidence to support or reject statements, in which constructivist educational practices must be of a high level in which students are involved in active research; 4) draw conclusions.

Milner, Templin and Czerniak (2010) argued that learning should implement activities such as: 1. asking open questions; 2) students start the research and design their own examinations; 4) the teacher asks students to write, present, discuss and maintain their group research.

For more details on the framework for K-12 Science Education (NRC, 2012), the following eight practices are important for studying science: (a) Asking questions and defining problems; (b) Develop and use models; (c) Planning and conducting investigations; (D) Analyzing and interpreting data; (f) Building an explanation; (g) Involved in evidence from evidence; and, (h) Obtain, evaluate and communicate information. 


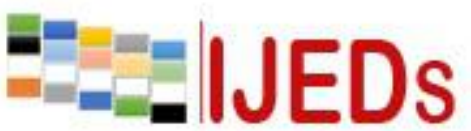

http://ijeds.ppj.unp.ac.id/index.php/IJEDS

The main purpose of discovery-based learning according to the National Research Council (NRC, 2000), as follows: (1) To learn students' desire and motivation to learn the principles and concepts of science, (2) Developing scientific skills the students so that they can work together looking like a scientist, (3) To develop. trusted students worked hard to acquire knowledge.

In addition, Sasseron and Carvalho (2008) says the teacher is not instilling scientific literacy at the beginning of the elementary school series and less work with students to address issues related to natural phenomena and the consequent impact on society and the environment. discuss. Viecheneski and Carletto (2013) suggest that it is to encourage the teachers in the first years of research students and curiosity epistemological, encourage them to make assumptions, ask questions, confront new ideas and gradually build up scientific concepts on natural phenomena, creatures life and the mutual relations between man, environment and teknology.Kemudian Arikan, Yildirim and Erbilgin (2016) proposes students to perform lower than the average in mathematics and science in international assessment programs, such as the program for International student assessment (PISA), and less explores the relationship teachers Among the new literacy, reading, mathematics and science achievements.

A reformist teacher must be able to put into practice. It is therefore important to examine questions, such as how you can start primary school teachers to interpret the recommendations for reform. such practices can motivate students to develop skills and skills based on scientific skills and convince students to see the relevance of scientific education for their lives; and promoting strategies, skills and abilities for students to succeed in scientific lessons. Blosser (1975) is of the opinion that one of the most important contributions a teacher can make to the success of students in the future of education offers them many opportunities to learn and use process skills.

\section{METHOD}

This research is a study of literature study by assessing different journals in terms of abstracts, introduction and conclusions in the journal section with regard to the learning process. The results of various literature reviews will be used to identify the 


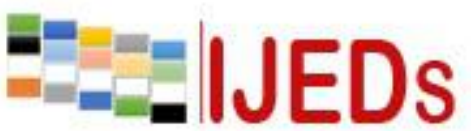

http://ijeds.ppj.unp.ac.id/index.php/IJEDS

causes of scientific attitudes and skills based on scientific literacy of underdeveloped students.

\section{RESULTS AND DISCUSSION}

The finding of this literature study is that with reformation learning will develop the scientific attitudes and skills of students. The thing found by Paul and Elder (2004) teaches that critical thinking skills are becoming increasingly important because students have to adapt to these changes by actively and expertly conceptualizing, implementing, analyzing, synthesizing and / or evaluating information collected from or produced by, observation, experience, reflection, reasoning or communication. Strengthened by the results of Meyer's research (2013) teachers say they should develop learning environments investigating authentic students to participate in conducting scientific, where students have the authority to put the issue of content, accountability in scientific practice in the classroom together to grab and take students, will produce disciplinary productive learning. By participating in authentic research, these students demonstrate scientific science and apply the standards of scientific discipline, identity and attitude, giving them a special structure of discipline to lead deeper participation in research.

Robinson, Dailey, Hughes and Cotabish (2014) say to stimulate the interest and enthusiasm of students in science, the scientific curriculum must emphasize general concepts, high thinking, research, technology and scientific processes. Robbins therefore suggests that the curriculum offers opportunities for students to apply scientific reasoning, to encourage reflection and collaboration, to involve students in quantitative problem solving and to expose students to the real work of scientists. This study provides an overview of students' attitudes towards science and predictive variables related to their attitudes.

The results of research based on scientific literacy with regard to the learning outdor conducted by Amini (2015) showing that outside classes are (outside) effective to improve the scientific attitudes of students, especially environmental care. The caring attitude is shown by the experiment of water purification and the composting of waste schools. Techakosita \& Wannapiroonb (2014) also recommends schools to provide part 


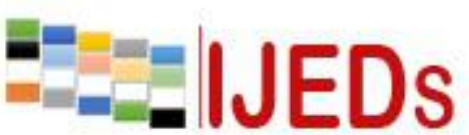

http://ijeds.ppj.unp.ac.id/index.php/IJEDS

of the Connectivism learning environment in scientific laboratories for augmented reality to improve scientific literacy. The findings Hacieminoglu (2016) showed that students have a negative attitude towards science, due to the application of science and technology curriculum that differs from the teacher and the classroom environment may lead to negative feelings about science. Traditional teaching and dependence on textbooks can increase the negative attitudes of students to science. Teachers must recognize the characteristics of each student in order to improve student attitudes towards science.

Understanding the science conception of teachers is a prediction of how they apply inquiry-based instruction. If teachers have different conceptions of scientific inquiry, the application of their curriculum will be different from the intended curriculum. So the transition from teacher learning practices requires a change in teacher paradigm, infrastructure support and physical infrastructure that must be provided by the Ministry (Chiang, Long, \& Bae, 2018; Anastasha, Fitria, \& Irdamurni, 2018). The nature of science learning defined as the science of nature is called science, can be classified into three parts, namely: natural science as a product, process, and attitude. The attitude in science learning is the scientific attitude. So, with science learning in elementary schools is expected to foster a scientific attitude like a scientist. As for the types of attitudes in question, namely: curiosity, confidence, honesty, unhurried, and objective attitude towards facts.

The scientific attitude was developed through the activities of students in science learning when conducting discussions, experiments, simulations, and project activities in the field. The development of scientific attitudes in elementary schools has a corresponding level of cognitive. According to Piaget, primary school age children ranging from 6-7 years to 11-12 years are in the category of concrete operational phase. A phase that shows a high level of curiosity to recognize the environment. In relation to the objectives of science education, students in elementary school must be given experience and opportunities to develop their ability to think and behave towards nature, so they can know the secrets and symptoms of nature. According to Sheldrake, Mujtaba, and Reiss (2017) conveying the integration of broader knowledge into everyday life in 


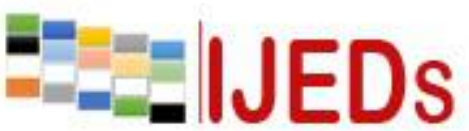

http://ijeds.ppj.unp.ac.id/index.php/IJEDS

the context of broad learning can help foster student interest, perceived usefulness of science, which can then help grow students' aspirations towards a scientific career.

\section{CONCLUSION}

Research that shows the importance of the science learning process carried out in a contemporary manner, where learning is student-centered, the teacher is only used as a facilitator in developing students' scientific attitudes and abilities (Plonczak, 2008; Robyn, Nichols, t Burgh, Haynes, 2014; Avraamidou, 2014; Barnard, 1953; Gillies, Nichols, Burgh, Haynes, 2013; Amini, 2015; Meyer, 2013; Hacieminoglu, 2016). The effectiveness of learning models has been put forward by various pedagogic experts who are effective in fostering the scientific attitude of students. The problem is the teacher who does not give the teacher the opportunity to explore the scientific / scientific learning process based on scientific literacy. Therefore, it is suggested that scientific learning abilities must be mastered by educators in fostering scientific attitudes and scientific litersis to students. In addition, the teacher training program must be reorganized to increase knowledge of science content and the ability of teacher pedagogy in improving scientific attitudes and literacy to students' learning

\section{REFERENCES}

Afriana, J., Permanasari, A., Fitriani, A. 2016. Project Based Learning Integrated to Stem to Enhance Elementary School's Students Scientific Literacy. JPII 5 (2)

Aktamis, H and E. Omer. 2008. The Effect of Scientific Process Skills Education on Students Scientific Creativity, Science Attitudes and Academic Achievements. Asia-Pacific Forum on Science Learning and Teaching, 9 (1)

Amini, R. 2015. Outdoor Based Environmental Education Learning And Its Effect in Caring Attitude Toward Environment. Indonesian Journal of Science Education, 4 (1), 43-47.

Anastaha, D. A., Fitria, Y., and Irdamurni, I. 2018. The effect of inquiry learning toward 5th grade students' understanding on sciences based on motivation in padang. Jurnal Aplikasi IPTEK Indonesia, 2(3).

Andrea, $\mathrm{T}$ and Czerniak. 2011. Elementary Science Students Motivation And LearningStrategyUse: Constructivist Classroom ContextualFactors In A Life ScienceLaboratory And A Traditional Classroom. The Association For Science Teacher Education, USA, 22:151-170. 


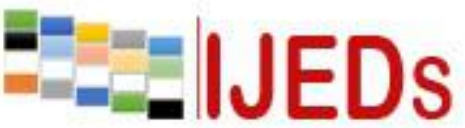

http://ijeds.ppj.unp.ac.id/index.php/IJEDS
International Journal of Educational Dynamics

Vol. 1 No. 1 (pp. 136-146) December 2018

p_ISSN 2655-4852

e ISSN 2655-5093

Arikan, S. dkk. 2016. Exploring the Relationship Among New Literacies, Reading, Mathematics and Science Performance of Turkish Students in PISA 2012. International Electronic Journal of Elementary Education, June 2016, 8(4), 573-588.

Avraamidou, L. 2014. Developing A Reform-Minded Science TeachingIdentity: The RoleOfInformal Science Environments. International Journal of Science Education, 25, 823-843.

Barnard, D. 1953. Special Problems InHigh School Science Education. Chapter V, 179-183.

Bybee, R. W. 2009. Program for International Student Assessment (PISA) 2006 and Scientific Literacy: A Perspective for Science Education Leaders, 18 (2)

Christopher and Rooks. 2010. Managing Inquiry-Based Science: Challenges In Enacting Complex ScienceInstruction In Elementary And Middle School Classrooms. Springer Science+Business Media,21, 227-240.

Chiang, S., Long, J., and Bae, Y. 2018. Action Research : First-Year Primary School Science Teacher's Conceptions on and Enactment of Science Inquiry in Singapore.

Demirbas, M. 2009. The Relationships between the Scientist Perception and Scientific Attitudes of Science Teacher Candidates in Turkey: A Case Study.Scientific Research and Essay Vol. 4

Désautels, J. and Larochelle, M. 1989. Qu'est-ce que le Savoir Scientifique? Points de VueD'Adolescents et D'Adolescentes. [What is Scientific Knowledge? Teenagers' Points ofView]. Québec: Presses de l’Université Laval

Eliana, T. R. C and V. B. Valquíria. 2015. Promovendo a Alfabetização Científica de Estudantes do Ensino Fundamental por meio da Aprendizagem Baseada em Problemas (Promoting Scientific Literacy of Elementary School Students through Problem-Based Learning). SCIENTIA CUM INDUSTRIA (SCI.CUM IND),3 (3), 86-92.

Gillies, N. B and Hayne. 2013. Primary Students' Scientific Reasoning And Discourse DuringCooperative Inquiry-Based Science Activities. International Journal Of Educational Research, 127-140.

Gonçalves, N. R and M. N. Azevedo. 2011. Ensino De Ciências No Fundamental 1: Perfil De Um Grupo De Professores Em Formação Continuada Num Contexto De AlfabetizaçãoCientífica(Elementary Science Education: Profile of a Group of Teachers Experiencing Continuous Formation in a Scientific Literacy Context).Ciência \& Educação, v. 17, n. 3, p. 705-720.

Hacieminoglu, E. 2016. Elementary School Students' Attitude toward Science. International Journal of Environmental \& Science Education, 11(2), 35-52.

Lúcia, H. S and M. P. de Carvalho Anna. 2008. Almejando A Alfabetização Científica No Ensino Fundamental: AProposição E A Procura De Indicadores Do Processo(Aiming at Scientific Literacy in Elementary School: a Proposal and the Search for Indicators of theProcess).Investigações em Ensino de Ciências 13(3), 333-352. 
http://ijeds.ppj.unp.ac.id/index.php/IJEDS

Meyer, X. 2013. Productive Disciplinary Engagement as a Recursive Process: Initial Engagement in a Scientific Investigation as a Resource for Deeper Engagement in the Scientific Discipline. International Journal of Educational Research, 184-198.

National Research Council. 1996. National Science Education Standards. Washington, Dc: National Academy Press.

National Research Council. 2000. Inquiry And The National Science Education Standards. Washington, Dc: National Academy Press.

National Research Council. 2012. A Framework For K-12 Science Education: Practices, CrosscuttingConcepts And Core Ideas. Washington, Dc: National Academy Press

Pinto, V. J and R. C. Marcia. 2013. Iniciação À Alfabetização Científica Nos Anos Iniciais:Contribuições De Uma Sequência Didática(Initiation to Scientific Literacy in Early Years of Elementary School: Contributions of a DidacticSequence).Investigações em Ensino de Ciências - V18(3), 525-543.

Plonczak, I. 2008. Science For All, Empowering Elementary School Teachers. Education, Citizenship And Social Justice, 3(2), 167-181

Robinson, A., Dailey, D., Hughes, G., and Cotabish, A. 2014. The Effects of a ScienceFocused STEM Intervention on Gifted Elementary Students' Science Knowledge and Skills.

Sheldrake, Mujtaba, and Reiss. 2013. Science Teaching and Students Attitudes and Aspirations: The Importance of Conveying the Applications and Relevance of Science. International Journal of Educational Research, 167-183.

Techakosita and Wannapiroonb. 2014. Connectivism learning environment in augmented reality science laboratory to enhance scientific literacy. Procedia Social and Behavioral Sciences. $2108-2115$

Turiman, P., O. Jizah., D. Adzliana., M. O. Kamisah. 2012. Fostering the 21st Century Skills Through Scientific Literacy and Science Process Skills. Procedia Social and Behavioral Sciences 59 (2012) $110-116$ 